\title{
Stock Market Development and Economic Growth: An Empirical Analysis of Zimbabwe (1989-2014)
}

\author{
Rabson Magweva' ${ }^{1}$, Tafirei Mashamba² \\ ${ }^{1}$ Great Zimbabwe University, Department of Banking \& Finance \\ P.O. BOX 1235 Masvingo, Zimbabwe \\ Email: rmagweva@gzu.ac.zw; magwevar@gmail.com \\ ${ }^{2}$ Great Zimbabwe University, Department of Banking \& Finance \\ P.O. BOX 1235 Masvingo, Zimbabwe \\ Email: tmashamba@gzu.ac.zW; cfamashamba@gmail.com
}

\begin{abstract}
The relationship between stock market development and economic growth varies across nations and regions. This relationship is of significance to regulatory authorities, investors and portfolio managers in their operations aimed at enhancing the welfare of the citizens and clients at large. The purpose of this study is to examine the relationship between these two variables in Zimbabwe for the period 1989 to 2014. The paper employed the Vector Error Correction Model approach after establishing the order of integration (unit root tests) and cointegration between variables. All the variables were found to be stationary at $1 \%$ level after first differencing using the Phillips-Peron tests. The long run relationship was negative, whereas the short run coefficients were insignificant. Though contrary to financial theory, the results, to a large extent, testify to what happened during the period. Based on these findings, the Zimbabwe Stock Exchange and Securities and Exchanges Commission are urged to come up with alternative products to lure new listings from the small to medium enterprises. It is also recommended that all the stakeholders focus beyond the Zimbabwe Stock Exchange to promote economic growth as the firms seem to raise funds from other sources.
\end{abstract}

Key words: cointegration, economic growth, stock market, unit root tests, vector error correction model

JEL codes: C01, C22, C13, G23

\section{Introduction}

The connection and co-movement between stock market development and economic growth have been heavily debated by financial economists as evidenced by the large number of published articles on the matter. A casual inspection of stock market prices and GDP, mostly in developed market economies, reveals that these variables tend to move together over time. What remains thorny to researchers is the question as to why such a relationship exists. Is it pure coincidence, wealth effect, or is the stock market a 'mirror' or a leading indicator of the economy or does the stock market drive the economy or the reverse? This study aims to answer such questions regarding Zimbabwe. 
The purpose of this paper is to examine the connection between the domestic stock market developments and economic growth. Though the local stock market has gone through a phase of phenomenal developments, it is not clear if such developments promoted or 'mirrored' or predicted economic growth or else such improvements were independent of the economy.

While most past papers show that stock market and financial development tend to be fair predictors of economic growth, for example King and Levine (1993), Rousseau and Watchel (1998), and Nuesser and Kuglar (1998), the results do not settle the causality issue. The importance of stock market for economic development lies in the functions it is prophesied to play. Such functions include among many: efficient allocation of scarce financial resources, long-term commitment of real capital, and reduction of transaction costs. Levine (2004) identifies four broad functions provided by the financial sector that reduce information and enforcement costs: (i) production of information on investment projects and capital allocation; (ii) monitoring and effective corporate governance enhancement; (iii) trading, diversification and management of risk; and (iv) savings mobilization. The way these five functions are supplied by the financial system, of which the stock market is part, influences saving rates, investment decisions, technological innovation and hence economic growth.

Even as early as in 1873, Bagehot noted the importance of stock market and financial sector at large for economic development. On the same train of argument, Schumpeter (1911) and Zivengwa et al. (2011) commented that a well-developed financial sector indirectly drives economic growth (indirect transmission mechanism). Thus, from the above perspectives, stock markets or the financial sector as a whole enhance and drive economic development hence the relationship between the stock market and economic growth is a causal one, whereby the stock exchange 'wags' the economy.

Patrick (1996) revealed that the financial system develops and follows where the economy at large leads. He also indicated that this demand-following procedure means finance is fundamentally passive and permissive in the growth process. Demetriades and Hussein (1996) confirmed this view indicating that an expansion of financial system is attributed to economic growth. Thus, banking on this view, economic development drives the financial sector development (the direction is now the other way round or else, the tail is now in charge).

At the extreme end of the debate, Lucas (1998) noted that financial development has no significant effect on economic growth. It was his belief that development economists were sceptical about the role the finances play in economic growth. In other words, there is no causal relationship in the finance-growth nexus.

Given the above divergent views on the link and causality between the financial system and economic growth, it is imperative that a study be carried out in a country like Zimbabwe, whose political and economic conditions are spectacularly dynamic. In a nation as Zimbabwe where unemployment is above $80 \%$ and economic fundamentals point southwards, economic growth strategies are direly needed by all. Thus, this study examines one of the ways (stock market development) which can be used to influence economic growth, so as to ascertain the relationship if any. 
The study will go a long way in informing the ministry of finance on the direction of the relationship and causality (if any) between the stock market and economic growth. Such piece of information will aid in policy formulation and course of action bearing in mind the results obtained from this study. Most studies have examined the link between the financial development and economic growth whereas this study narrows down to stock market thereby filling in the knowledge gap in literature.

\section{Literature Review}

Before highlighting the works of other authors, a general overview of the stock exchange under study is provided. The now ZSE has a long historical development spanning over a century as explained below.

\section{Pre-independence Period (before 1980)}

The first bourse to open its doors in Rhodesia (now Zimbabwe) was launched in 1896 in the now Bulawayo in an attempt to harness financial resources to spearhead gold mining. This stock exchange operated for only six years and was officially closed, as asserted in Lynton Edwards Stockbrokers (2011) handbook.

In the same train of thought, another exchange was opened in the now Mutare in 1896 but also closed its doors in 1924 after realising that the mineral resources were not that extensive hence no need run an exchange to fund mining firms especially. Between 1900 and 1930, another exchange was in operation in the now Gweru. For the second time a new bourse was opened in the now Bulawayo in 1946 and subsequently in 1951 another separate bourse was opened in the now Harare according to Imara Securities handbook (2012). In 1974, an Act was passed consolidating the two exchanges under the legal and operational framework based in the now Harare under the name Rhodesia Stock Exchange (as the two exchanges were interconnected via a telephone network).

\section{Post-independence Era (1980 to 2014)}

When the country gained its independence in 1980, the Rhodesia Stock Exchange was renamed Zimbabwe Stock Exchange (ZSE). The exchange lists counters in all sectors of the economy such as agriculture, tourism, telecommunication and mining. There are only two indices on the bourse, namely, mining and industrial. The mining index is for all listed mining firms and the rest of the counters constitute the industrial index.

Trading is via a call over system using an open outcry system once a day between 10-12noon. Only stockbrokers who own a seat are allowed in the trading pit and settlement is physical and normally $T+7$. Foreign participation on the exchange was introduced in mid-1993 following the partial lifting of exchange control restrictions. Individually, a foreigner can hold only up to $10 \%$ of any listed company without any recourse to the exchange control. Collectively, foreign ownership in a listed company may not exceed $40 \%$ of the issued capital of the company excluding holdings acquired before mid-1993 according to Imara Securiries handbook (2012). 
While the total turnover ratio of the ZSE has been declining, the turnover ratio for foreign purchases increased from $0.48 \%$ in June 2009 to $1.31 \%$ in January 2014 according to Chiwunze (2014). Liquidity squeeze has enabled foreign investors to increasingly dominate trade on the ZSE. During this period (especially 2004-8) Zimbabwean economy as a whole went under hard testing times punctuated with company closures, negative economic growth rates, very high unemployment rates, sky rocketing inflation, and devaluation of the local currency.

Surprisingly enough, during this period, abnormal profits through ethical and unethical means were realised on the exchange to an extent that ZSE was among the best performing stocks in $2007 / 8$ period though the economy at large was in shambles. This really boggles the mind of any analyst. The extent of underhand dealings was so high that the exchange was closed from mid-November 2008 to midFebruary 2009 as it was labelled an epicentre of economic destruction and a vehicle of economic destruction by the then Central Bank governor, Gono (2008).

In the present multicurrency era, the ZSE operates according to the Securities Act Chapter 24:25 of 2004 operationalised in 2008. It is wholly owned by the members and is under the supervision of the Securities and Exchanges Commission of Zimbabwe (SECZ). The following improvements are currently in the pipeline in an effort to improve the ZSE efficiency: demutualisation of the bourse, electronic trading and establishing a Centralised Securities Depository among others.

Since the introduction of multicurrency system in February 2009, ZSE has been hit by a number of delisting. In 2008 there were 81 counters and in mid-2014 there were only 66 counters. Reasons cited for such decline include: undervaluation of stocks, liquidity crunch in the economy, stringent listing requirements and lack of transparency among many, as purported by Chowa et al. (2014).

\section{Theoretical Review}

Properly addressing the relationship between stock market and economic growth will provide answers as to what the new finance ministers or treasury should do about stock markets. The stock market is in the focus of the financial economists and policy makers because of the perceived benefits and costs it provides for the economy.

Nyong (1997) argued that the stock market is viewed as a complex institution imbued with an inherent mechanism through which long-term funds of the major sectors of the economy are mobilized, harnessed and channelled to various sectors of the economy. The development of the capital market, and apparently the stock market, provides opportunities for greater funds mobilization, improved efficiency in resource allocation and provision of relevant information for appraisal (Inanga and Emenuga, 1997). It is imperative to note that new capital expenditure can only enhance economic growth if it is used for expansionary purposes not to repair corporations' equipment.

Stock market contributes to economic growth through the specific services or functions it performs either directly or indirectly, as confirmed by Jecheche (2011). Such vital services include long-term capital for public and private institutions, 
corporate governance improvement and the creation of liquidity which bestows investors with some control over their long-term investments. As such, the nature and economic significance of the relationship between stock market development and growth vary according to a country's level of economic development with a larger impact in less developed economies, as argued by Filler et al. (1999).

The view that stock market developments drive the economy is based on the assumption that it first affects specific macroeconomic variables such as consumption, investment, and money supply. The market might affect consumption via its influence upon dividend income, or wealth or expectations (Levine, 2004). It might affect investment spending via stock yields and the cost of finance. It might have affected either consumption or investment spending via its impact on the supply of money or credit. This view is premised on the belief that whatever happens on stock markets is carried over to consumption and investment decision by individuals and firms (Nyong, 1997). Going a bit further, for a stock market to induce economic growth it means implicitly assuming that consumer confidence and consequent spending are drivers of economic growth.

Interestingly, Robinson (1952) and Levine (1997) contend that enterprise precedes finance implying that finance at large is passive and permissive in the growth process. Regarding this view, the stock market is not more than a mere leading indicator of the economy. It should be noted that the predictive powers of the stock market are very low hence the common adage 'stock markets have predicted 10 out of the last three recessions'.

Economic theory (traditional stock pricing theory) and fundamental analysis suggest that there should be a strong positive link between economic activity and security prices, given that the stock price is the discounted present value of the firm's pay-out and other related cash flows. Regarding this view, stock prices predict economic growth (leading indicator).

Arguably, Tobin (1969) came up with Tobin Q which is a coefficient or ratio of the market value of current capital to the cost of replacement capital. When share prices are high, the value of the firm relative to the replacement cost of its stock of capital (Tobin's Q) is also high. Consequently, this leads to increased investment expenditure and thus to higher aggregate economic output as firms find it easier to finance investment expenditures. This occurs because investment would be easier as it would require a lower share offering in a situation of a high share price. Modigliani (1971) proposed that a permanent increase in security prices results in an increase in the individual's wealth holdings, and therefore in a higher permanent income and increased consumption levels. In the case of pension pay-outs, the effect might be loud and clear provided the national demographics are in favour of the retired.

However, Green (1972) argued that the marginal propensity to consume out of net worth was 0.06 . He also noted that spending decisions are not based on day-to-day or even monthly fluctuations in net worth but upon some subjective perception of more permanent changes in net worth. Concurring with this view is the rule of thumb echoing that a 100 Euro decline in value of stock reduces private consumption by 1-2 Euros in Germany. This means the change in consumption might be very small in 
developing nations where stock ownership is for the elite few and stocks figure less in investor asset allocation. For example, in 1997, MacEwan noted that $10 \%$ of the Americans owned $85 \%$ of all stock and $71 \%$ owned no stock. It follows that there would not be much changes in mass consumption items, but maybe luxury goods. If $71 \%$ owned no stocks in a developed nation where investment knowledge and stock trading is readily available, the figure is likely to be higher in the developing world. Above all, there is need to note how much of the sales/consumption at large is driven by stock market developments or stock price changes, lest we might give credit where it is neither due nor worthy.

Another possibility through which stock prices impact output is referred to as the financial accelerator (Bernanke, 1986; Kiyotaki and Moore, 1997). It focuses on the impact that stock prices have on firms' statement of financial position. A firm's ability to borrow depends substantially on the collateral (equity, through the bootstrapping strategy) they can offer, which increases in scenarios where their stock price increases. Hence, if such is prevailing, higher credit can be raised, which in turn can be used for investment purposes and thereby trigger an expansion in economic activity.

Jecheche (2011) noted that stock market prices do not accurately reflect the underlying fundamentals when speculative bubbles emerge in the market. In such cases there is deviation from all the finance and economic theories of asset pricing (Binswanger, 2000). Irrational exuberance and the so called 'animal spirit' will guide the stock market in becoming a casino.

Critics further argue that stock market liquidity may negatively influence corporate governance because very liquid stock market may encourage investor myopia hence no incentive for corporate control free-ridership among shareholders (Bhide, 1993). It also argued that stock markets generate perverse incentives, rewarding managers for their success in financial engineering rather than creating new wealth through organic growth thereby promoting short-termism among managers (Singh, 1997).

These problems are amplified in developing countries with their weaker regulatory institutions and greater macroeconomic volatility. These serious limitations of the stock market have led many analysts to question the importance of the system for promoting economic growth in African countries including Zimbabwe.

For most developing economies, there is very little empirical evidence on the relationship between stock market development and economic growth. In Zimbabwe, such evidence is almost non-existent with the exception of one study by Zivengwa et al. (2011) and another one by Jecheche (2011), (with the exception of the unpublished scrolls).

\section{Empirics on the Relationship and Causality Issues}

Whether the financial sector (through intermediation) causes economic growth or economic growth enhances the financial sector development is a cause for concern for many authors. Cameron et al. (1967) believes that the financial systems may be 
both growth-inducing and growth-induced. However, he stresses the important role of the quality of their services and the efficiency with which they are provided.

When the financial sector's development stimulates economic growth, it is commonly referred to as the supply-leading hypothesis (Eschenbach, 2004). Levine and Zervos (1998) and Fry (1995) are among many other researchers who found evidence supporting this hypothesis. The hypothesis that the financial sector promotes economic growth is largely supported by empirical studies. Goldsmith (1969), McKinnon (1973) and Ghani (1992) are among the advocates of this hypothesis.

When the economy stimulates financial growth, it is referred to as the demandfollowing hypothesis. For demand-following, economic development establishes a demand for financial services, which is passively satisfied by a growing financial sector (Eschenbach, 2004). Boulila and Trabelsi (2002) presenting results for the Middle East and North African countries show causality running predominantly from economic growth to financial development.

Demetriades and Hussein (1996) also find little systematic evidence in favour of the view that finance is a leading factor in the process of economic growth. They found that for the majority of the countries they examine, causality is bi-directional.

Campbell (1987) uses the log-linear asset pricing framework to study the empirical relationship between stock prices and output. In his work, the log-price dividend ratio is regressed against output growth. The results are statistically insignificant in France, Germany, the UK, Japan and the US. According to Campbell, stock prices have little predictive content with respect to output.

Humpe and Macmillan (2005) analysed the extent to which macroeconomic variables explained stock market movements in the US and Japan. Using a log-linear model, they found that a 1 per cent increase in industrial production triggered a 1.09 per cent increase in US stock prices whilst a 1 per cent increase in Japanese industrial production triggered a 0.4 per cent increase in Japanese stock prices. Both parameters were highly statistically significant and drive home the point that the effect differs among nations.

Hence, given these divergent views and results, the debate in the literature and empirics on the link between stock prices and the economy remains inconclusive, thus justifying the need for a closer look at the Zimbabwean case.

\section{Methodology}

This paper adopted a restricted Vector Autoregressive (VAR) model also known as Vector Error Correction Model (VECM) which is effectively a time series analysis where all the variables in question are treated as endogenous to establish the dynamic relationships among variables. The VECM was used to establish the dynamic interrelationships between economic growth and stock market development after testing and ensuring that the variables are stationary and cointegrated which justifies the use of VECM. 
All the variables, except GDPPC which had some negative values, were expressed in logarithms to smoothen the data and to reduce the likelihood of heteroskedasticity. The variables of the model therefore became: GDPPC, LMCGDP, LTOR and LTVGDP (the meaning of the abbreviations is explained below, in chapter Variables of interest). As in any meaningful econometric analysis, the variables were tested for stationarity in order to establish the order of integration for each variable. This test for unit root also provides a direction on whether or not to carry out cointegration analysis. After testing for long run relationship using the maximum likelihood procedure of Johansen (1988) and Johansen and Juselius (1992), the VECM was then used in examining the short and long run relationship between stock market development and economic growth.

\subsection{Unit Root Tests}

In testing the existence of stochastic non-stationarity the study employed the Phillips-Perron (1988) unit root test as adopted by Maduka and Onwuka (2013) and Hamdi et al. (2013) who commented on the low power of Augmented Dickey Fuller (ADF) test. ADF test has proved to be biased towards non-rejection of an alternative hypothesis of unit root tests especially in the existence of a structural change according to Perron (1989, 1990). As in the Zimbabwean economy, around 1990 the government liberalized the economy, thus a break in the variables is most probable, as noted by Ndlovu (2013). It is against this background that the Phillips Perron methodology/test was used in this study. According to Brooks (2008), the PhilipsPerron unit root test, which captures the effect of autocorrelation, is actually a modified Augmented Dickey Fuller test. It takes the following form:

$$
\Delta y_{t}=\rho y_{t-1}+\sum_{i=1}^{p} \alpha_{i} \Delta y_{t-1}+u_{t}
$$

Where the regressors now include the lagged values of the dependent variable. The test is on whether $\rho$ is significantly different from zero or not.

\subsection{Cointegration Test}

To establish the existence of long run relationship among the variables of interest, cointegration test was carried out. This study employed the Johansen approach which enables the identification of more than one cointegrating vectors. This test uses two statistics, namely the Trace and Maximum Eigenvalues, which are formulated as follows, as presented by Brooks (2008):

$$
\begin{aligned}
& Y_{\text {trace }}(r)=-T \sum_{i=r+1}^{g} \ln \left(1-\hat{Y}_{i}\right) \\
& Y_{\max }(r, r+1)=-T \ln \left(1-\hat{\mathrm{Y}}_{r+1}\right)
\end{aligned}
$$

In this scenario, $r$ is the number of cointegrating vectors, $\hat{Y}_{i}$ is the $i^{\text {th }}$ ordered eigenvalue from the long run coefficient matrix. The trace is a joint test where the null is the number of cointegrating equations is less than or equal to $r$, against 
alternative of more than $r$. The max conducts separate tests on each eigenvalue and has its null $r$ cointegrating vectors against $r+1$.

\subsection{VECM Estimation}

E-views 7 automatically analyse the variables in their first differenced form in the case of VECM, hence the variables were not transformed as this was done automatically in the system. Thus the variables were used in their levels.

In our analysis, the following VAR (equations 4 and 5) model utilized by Zivengwa et al. (2011) was therefore used:

$$
\begin{gathered}
X_{t}=\sum_{i=1}^{n} \beta_{i} X_{t-i}+\mu_{t} \\
\text { Where } X_{t}=\left[\begin{array}{c}
G D P P C_{t-i} \\
M C G D P_{t-i} \\
T O R_{t-i} \\
T V G D P_{t-i}
\end{array}\right]
\end{gathered}
$$

which is a $4 \times 1$ vector of variables and $\beta_{i}$ up to $\beta_{n}$ is a $1 \times 4$ vector of coefficients and $\mu_{t}$ is a vector of error terms.

\subsection{Data and Data Sources}

The study made use of economic data from 1989 to 2014, as this is the data currently available as far as Zimbabwe is concerned. The 2008 data is not available for stock market development proxies due to the temporary closure or suspension of trade which hit the bourse as already highlighted. To cater for the missing data in the year 2008, the mean substitution method was used to create new observations (Rubin et al., 2007). The data was obtained from the International Financial Statistics (IFS 2014) and World Bank Development Indicators for 2014. These two sources were used coupled with the data from ZimStats, which is the official custodian of all Zimbabwean data.

\section{Variables of Interest}

In this study, the proxies for stock market development are: Market capitalisation of listed firms as a percentage of GDP; stocks traded turnover ratio and stocks traded total value as a percentage of GDP. The variables are hereby explained below.

Economic Growth (GDPPC): the study used real GDP per capita growth rate as a proxy for economic growth as in the study by Zivengwa et al. (2011), Tuncer and Alovsat (2000) and Levine and Lervos (1996). This variable reveals the actual domestic production per person which generally has a bearing on the welfare of a country's citizens.

Stock Market Size (MCGDP): a widely used and adopted indicator for stock market size is stock market capitalization as a ratio to GDP as used by Nowbutsing (1999), and Van Nieuwerburgh et al. (2005). This variable measures the ratio of market capitalization to GDP and is expected to be positive and significant. 
Stock market turnover (TOR): this variable captures the liquidity and efficiency of the stock market, and is calculated as the ratio of the value of total shares traded to market capitalization as used by Beck and Levine (2003).

Stocks traded total value (TVGDP): Rousseau and Wachtel (2000) and Beck and Levine (2004) use this measurement and it is given as the ratio of value shares traded to nominal GDP, which means it captures the level of trading compared to economic growth.

\section{Results and Interpretation}

As in any meaningful econometric analysis, the variables were tested for stationarity in order to establish the order of integration for each variable. This test for unit root also provides a direction on whether or not to carry out cointegration analysis. After testing for long run relationship using the maximum likelihood procedure of Johansen (1988), the VECM was used in examining the short and long run relationship between stock market development and economic growth.

\subsection{Stationarity Tests Results}

All the variables were not stationary in levels. They all became stationary after first differencing as shown in Table 1 below:

Table 1 Unit root tests

\begin{tabular}{lccccc}
\hline Variable & $\begin{array}{c}\text { P-P } \\
\text { statistic }\end{array}$ & $\begin{array}{c}\text { Critical } \\
\text { value }\end{array}$ & $\begin{array}{c}\text { Integration } \\
\text { order }\end{array}$ & Decision & $\begin{array}{c}\text { Significance } \\
\text { level }\end{array}$ \\
\hline \hline GDPPC & -9.84095 & -3.769597 & $\mathrm{I}(1)$ & Stationary & $1 \%$ \\
\hline LMCGDP & -10.90149 & -3.769597 & $\mathrm{I}(1)$ & Stationary & $1 \%$ \\
\hline LTOR & -7.50750 & -3.769597 & $\mathrm{I}(1)$ & Stationary & $1 \%$ \\
\hline LTVGDP & -8.05588 & -3.808527 & $\mathrm{I}(1)$ & Stationary & $1 \%$ \\
\hline
\end{tabular}

Source: Authors' calculations from E-views 7

As all the variables were $\mathrm{I}(1)$, this prompted the need for testing the existence of long run relationship between the variables.

\subsection{Cointegration of the Variables}

To establish the existence of long run relationship among the variables of interest, cointegration test was carried out. Results in Table 2 indicate that both the Maximum Eigen values and Trace statistics reject the null hypothesis of 'no cointegrating equation'. This effectively means there is one error correction term as the 'at most one' null hypothesis is accepted. Due to the limited sample size, lag selection was limited to one period as recommended by Zivengwa et al. (2011). Looking at the long run coefficients from Table 3 below, the long run relationship between economic growth and market capitalisation is a negative one. The same applies to turnover ratio. 
Table 2 Cointegration test results

\begin{tabular}{cccccc}
\hline $\begin{array}{c}\text { Hypothesized } \\
\text { no. of CE }\end{array}$ & $\begin{array}{c}\text { Eigen } \\
\text { value }\end{array}$ & $\begin{array}{c}\text { Trace } \\
\text { statistic }\end{array}$ & $\begin{array}{c}\mathbf{0 . 0 5} \\
\text { critical } \\
\text { value }\end{array}$ & $\begin{array}{c}\mathbf{0 . 0 1} \\
\text { critical } \\
\text { value }\end{array}$ & Prob.*** \\
\hline \hline None & 0.98568 & 316.2008 & 150.5588 & 167.7165 & $0.0393^{*}$ \\
\hline At most one & 0.81495 & 122.194 & 122.8037 & 125.9873 & 0.0783 \\
\hline At most two & 0.62456 & 98.9087 & 115.8096 & 118.7345 & 0.4451 \\
\hline
\end{tabular}

Note: ***MacKinnon-Haug-Michelis 1999 p-values, $*$ indicates rejection of null hypothesis at $5 \%$ and $1 \%$ levels.

Source: Authors' calculations from E-views 7

This is contrary to financial theory whereby the relationship is expected to be positive as highlighted by King and Levine (1993), Rousseau and Watchel (1998), and Nuesser and Kuglar (1998). As already indicated, during the post-2000 era, the Zimbabwean economy plunged cumulatively until 2009 when the local currency was demonetized. During this period of economy dwindling, most investors ventured into the capital market as the only source of returns. This led to the increase in market capitalisation solely driven by speculative tendencies not necessarily reflecting the economy nor a forecast.

Table 3 Long run estimates

\begin{tabular}{|c|c|}
\hline \multicolumn{2}{|c|}{ Vector Error Correction Estimates } \\
\hline $\begin{array}{l}\text { Date: } 11 / 28 / 15 \text { Tin } \\
\text { Sample (adjusted): } \\
\text { Included observation } \\
\text { Standard errors in ( }\end{array}$ & $\begin{array}{l}5: 31 \\
2014 \\
\text { after adjustments } \\
\text { statistics in [ ] }\end{array}$ \\
\hline CointegratingEq: & CointEq1 \\
\hline $\operatorname{GDPPC}(-1)$ & 1.000000 \\
\hline LMCGDP(-1) & $\begin{array}{r}-64.06302 \\
(15.5432) \\
{[-4.12162]}\end{array}$ \\
\hline $\operatorname{LTOR}(-1)$ & $\begin{array}{r}-59.32143 \\
(13.1863) \\
{[-4.49872]} \\
\end{array}$ \\
\hline LTVGDP(-1) & $\begin{array}{r}61.63344 \\
(14.5439) \\
{[4.23775]} \\
\end{array}$ \\
\hline C & 287.5266 \\
\hline
\end{tabular}

Source: Authors' calculations from E-views 7

For Zimbabwe, the results above make a lot of sense due to the fact that during the period under study, the stock exchange was marred with irregularities, inefficiencies, and speculation (and even termed the centre of economic destruction). The bourse was prevalent not in promoting the welfare of firms at large, but personal gains from price movements against the background of company closure or reduced capacities.

Instead of channelling funds into economic activities which were not profitable during the post-2000 era, individuals and some firms gambled on the bourse (thereby increasing capitalisation and turnover ratio) though the economic growth declined. 
Thus, the local bourse lost its essence of existence like any other financial institution during the period where depositing funds with a bank was actually a financial suicide. Surprisingly, the coefficient of stocks traded total value is positive meaning the variables moved in the same direction during the period in Zimbabwe. As expected from financial theory, these variables should be positively related as they reflect what is happening in the economy.

\subsection{VECM Estimation Results}

E-views 7 automatically analyse the variables in their first differenced form in the case of VECM, hence the variables were not transformed as this was done automatically in the system. Thus the variables were used in their levels. The results obtained are shown in Table 4 below:

Table 4 VECM results

\begin{tabular}{|c|c|c|c|c|}
\hline \multicolumn{5}{|c|}{ Vector Error Correction Estimates } \\
\hline \multicolumn{5}{|c|}{$\begin{array}{l}\text { Date: } 11 / 28 / 15 \text { Time: } 15: 31 \\
\text { Sample (adjusted): } 1992 \text { 2014 } \\
\text { Included observations: } 23 \text { after adjustments }\end{array}$} \\
\hline \multicolumn{5}{|c|}{ Standard errors in ( ) \& t-statistics in [ ] } \\
\hline CointegratingEq: & CointEq1 & & & \\
\hline $\operatorname{GDPPC}(-1)$ & 1.000000 & & & \\
\hline $\operatorname{LMCGDP}(-1)$ & $\begin{array}{r}-64.06302 \\
(15.5432) \\
{[-4.12162]}\end{array}$ & & & \\
\hline $\operatorname{LTOR}(-1)$ & $\begin{array}{r}-59.32143 \\
(13.1863) \\
{[-4.49872]}\end{array}$ & & & \\
\hline $\operatorname{LTVGDP}(-1)$ & $\begin{array}{r}61.63344 \\
(14.5439) \\
{[4.23775]}\end{array}$ & & & \\
\hline C & 287.5266 & & & \\
\hline Error Correction: & D(GDPPC) & D(LMCGDP) & D(LTOR) & D(LTVGDP) \\
\hline CointEq1 & $\begin{array}{r}-0.477505 \\
(0.29412) \\
{[-1.62352]}\end{array}$ & $\begin{array}{r}0.024376 \\
(0.03497) \\
{[0.69700]}\end{array}$ & $\begin{array}{c}0.023664 \\
(0.02776) \\
{[0.85252]}\end{array}$ & $\begin{array}{c}0.027518 \\
(0.03802) \\
{[0.72372]}\end{array}$ \\
\hline $\mathrm{D}(\mathrm{GDPPC}(-1))$ & $\begin{array}{r}-0.345749 \\
(0.29683) \\
{[-1.16482]}\end{array}$ & $\begin{array}{c}-0.021758 \\
(0.03529) \\
{[-0.61648]}\end{array}$ & $\begin{array}{c}0.017883 \\
(0.02801) \\
{[0.63837]}\end{array}$ & $\begin{array}{c}0.003203 \\
(0.03837) \\
{[0.08347]}\end{array}$ \\
\hline $\mathrm{D}(\mathrm{GDPPC}(-2))$ & $\begin{array}{r}-0.194605 \\
(0.21429) \\
{[-0.90815]}\end{array}$ & $\begin{array}{c}0.002912 \\
(0.02548) \\
{[0.11428]}\end{array}$ & $\begin{array}{c}0.001100 \\
(0.02022) \\
{[0.05441]}\end{array}$ & $\begin{array}{c}0.003097 \\
(0.02770) \\
{[0.11179]}\end{array}$ \\
\hline $\mathrm{D}(\operatorname{LMCGDP}(-1))$ & $\begin{array}{r}-22.81428 \\
(15.6289) \\
{[-1.45975]}\end{array}$ & $\begin{array}{r}0.808915 \\
(1.85839) \\
{[0.43528]}\end{array}$ & $\begin{array}{r}1.877615 \\
(1.47499) \\
{[1.27296]}\end{array}$ & $\begin{array}{r}2.391897 \\
(2.02048) \\
{[1.18382]}\end{array}$ \\
\hline $\mathrm{D}(\operatorname{LMCGDP}(-2))$ & $\begin{array}{r}-11.15065 \\
(8.42917) \\
{[-1.32286]}\end{array}$ & $\begin{array}{r}0.494714 \\
(1.00229) \\
{[0.49359]}\end{array}$ & $\begin{array}{r}0.667743 \\
(0.79551) \\
{[0.83939]}\end{array}$ & $\begin{array}{r}0.998643 \\
(1.08971) \\
{[0.91643]}\end{array}$ \\
\hline $\mathrm{D}(\operatorname{LTOR}(-1))$ & $\begin{array}{r}-14.55694 \\
(14.4290) \\
{[-1.00887]}\end{array}$ & $\begin{array}{c}1.318899 \\
(1.71570) \\
{[0.76872]}\end{array}$ & $\begin{array}{r}1.475993 \\
(1.36174) \\
{[1.08390]}\end{array}$ & $\begin{array}{r}2.069148 \\
(1.86535) \\
{[1.10925]}\end{array}$ \\
\hline
\end{tabular}




\begin{tabular}{crrrr}
\hline Error Correction: & D(GDPPC) & D(LMCGDP) & D(LTOR) & D(LTVGDP) \\
\hline & 1.586569 & 0.881318 & -0.262128 & 0.455239 \\
D(LTOR $(-2))$ & $(5.77532)$ & $(0.68672)$ & $(0.54505)$ & $(0.74662)$ \\
& {$[0.27472]$} & {$[1.28336]$} & {$[-0.48092]$} & {$[0.60973]$} \\
\hline & 14.76821 & -1.048858 & -2.074048 & -2.451003 \\
D(LTVGDP(-1)) & $(15.2734)$ & $(1.81612)$ & $(1.44144)$ & $(1.97452)$ \\
& {$[0.96692]$} & {$[-0.57753]$} & {$[-1.43887]$} & {$[-1.24131]$} \\
\hline \multirow{3}{*}{ D(LTVGDP(-2)) } & -1.259788 & -1.011457 & 0.185359 & -0.647763 \\
& $(5.36688)$ & $(0.63816)$ & $(0.50650)$ & $(0.69382)$ \\
& {$[-0.23473]$} & {$[-1.58496]$} & {$[0.36596]$} & {$[-0.93362]$} \\
\hline & 1.802496 & 0.162490 & 0.060594 & 0.172155 \\
C & $(1.63904)$ & $(0.19489)$ & $(0.15469)$ & $(0.21189)$ \\
& {$[1.09973]$} & {$[0.83374]$} & {$[0.39172]$} & {$[0.81247]$} \\
\hline
\end{tabular}

Source: Authors' calculations from E-views 7

From the table above, there are four models whereby each variable is considered a dependent variable. Our interest is only in one model where the economic growth is the dependent variable.

Considering the short run coefficients in the model of interest, as in Table 5 below, all the coefficients are insignificant at even 10\%, meaning that the independent variables cannot be used to predict, in the short run, the dependent variable, economic growth, in Zimbabwe.

Table 5 Model of interest

\begin{tabular}{|c|c|c|c|c|}
\hline $\begin{array}{l}\text { Dependent Va } \\
\text { Method: Least } \\
\text { Date: } 11 / 28 / 1 \\
\text { Sample (adjus } \\
\text { Included obse }\end{array}$ & $\begin{array}{l}\text { D(GDPPC) } \\
\text { res } \\
\text { ne: } 16: 36 \\
\text { 1992 } 2014 \\
\text { is: } 23 \text { after ac }\end{array}$ & justments & & \\
\hline \multicolumn{5}{|c|}{$\begin{array}{l}\mathrm{D}(\mathrm{GDPPC})=\mathrm{C}(1) *(\mathrm{GDPPC}(-1)-64.0630151345 * \operatorname{LMCGDP}(-1)- \\
59.321430158 * \operatorname{LTOR}(-1)+61.6334374614 * \operatorname{LTVGDP}(-1)+ \\
287.526579007)+\mathrm{C}(2) * \mathrm{D}(\mathrm{GDPPC}(-1))+\mathrm{C}(3) * \mathrm{D}(\mathrm{GDPPC}(-2))+\mathrm{C}(4) \\
* \mathrm{D}(\text { LMCGDP }(-1))+\mathrm{C}(5) * \mathrm{D}(\operatorname{LMCGDP}(-2))+\mathrm{C}(6) * \mathrm{D}(\operatorname{LTOR}(-1))+\mathrm{C}(7) \\
* \mathrm{D}(\mathrm{LTOR}(-2))+\mathrm{C}(8) * \mathrm{D}(\operatorname{LTVGDP}(-1))+\mathrm{C}(9) * \mathrm{D}(\operatorname{LTVGDP}(-2))+\mathrm{C}(10)\end{array}$} \\
\hline & Coefficient & Std. Error & t-Statistic & Prob. \\
\hline$C(1)$ & -0.477505 & 0.294117 & -1.623520 & 0.1328 \\
\hline$C(2)$ & -0.345749 & 0.296827 & -1.164816 & 0.2687 \\
\hline$C(3)$ & -0.194605 & 0.214287 & -0.908151 & 0.3833 \\
\hline$C(4)$ & -22.81428 & 15.62894 & -1.459746 & 0.1723 \\
\hline$C(5)$ & -11.15065 & 8.429170 & -1.322864 & 0.2127 \\
\hline$C(6)$ & -14.55694 & 14.42895 & -1.008871 & 0.3347 \\
\hline$C(7)$ & 1.586569 & 5.775321 & 0.274715 & 0.7886 \\
\hline$C(8)$ & 14.76821 & 15.27344 & 0.966921 & 0.3544 \\
\hline$C(9)$ & -1.259788 & 5.366877 & -0.234734 & 0.8187 \\
\hline$C(10)$ & 1.802496 & 1.639036 & 1.099729 & 0.2949 \\
\hline
\end{tabular}

Source: Authors' calculations from E-views 7

Since 1995, after the Economic Structural Adjustment Program, the Zimbabwean economy has slowly moved into the informal sector and the rate increased after the 
2000 land reform programme. Thus the general populace's economic activity went off economic radar - not captured in economic growth statistics.

The small to medium enterprises (SMEs) and the informal sector from which the people still carry out their economic activities cannot raise funds from the local bourse, thus drawing a rift between the economy and stock exchange. On top of that, some firms delisted from the local bourse as the share prices were much depressed against the background of liquidity squeeze, whereas the listing fees were high.

This clearly shows and evidences that the economic activity in Zimbabwe and ZSE developments are likely to be independent of each other. That is, most of the firms do not raise funds from the ZSE - which might be ascribed to stringent SECZ requirements and low new issue subscriptions.

Most interestingly, ZSE trades are dominated by foreigners, as already noted, hence whatever happens on the bourse might be determined by external influences not the welfare or income of Zimbabweans. On the same train of thoughts, even dividends, if any, will not be expended locally. So the volume of trade, market capitalisation and other stock market measures do not fully mirror or predict the economy.

Of critical importance is also the fact that stock prices are not solely driven by economic fundamentals. Thus, on ZSE, stock prices might have been a function of other non-economic factors such as emotions, cognitive psychology and expectations.

Table 5 which clearly stipulates the coefficients and p-values of the model of interest where GDPPC is the dependent variable shows that the error correction term (C1 the coefficient of the cointegrated model), though negative as expected, is not significant. This means there is no long run causality running from stock market development to economic growth, that is, in the long run stock market development has no influence on economic growth.

Though contrary to finance and economic theory (King and Levine, 1993; Rousseau and Watchel, 1998; and Nuesser and Kuglar, 1998) this is actually what transpired in Zimbabwe during the period under review. In the so called 'lost decade', the stock market posted very lucrative returns though the economy at large was on the brink of collapse. Thus, the ZSE neither mirrored the economy nor predicted it. During the period, the stock market was full of speculators which led to stock prices rising to levels beyond any economic reason save for greed. This led to the temporary closure of the bourse as the authorities could no longer stomach the ills manifested by the exchange.

\section{Conclusions and Recommendations}

The study determined the relationship between economic growth and stock market development in Zimbabwe from 1989 to 2014 using the VECM approach. The results evidence the lack of a significant relationship between the variables in the short run. Thus, the development of ZSE is not a significant variable in explaining economic developments at least in the short run. This is not surprising given that stock markets in most developing nations are not a true representation of the economy as only a 
handful of stocks are listed compared to the firms operating in the economy (both public and private).

The insignificant explanatory power of stock market developments is amplified by the existence of viable informal sector and SMEs (which are not listed but at least captured in economic growth measures). Though not captured by ZSE metrics, the role of the informal sector and SMEs in Zimbabwe is significant. As such, ZSE does not significantly reflect or enhance economic growth of the nation.

As expected from the Zimbabwean scenario, the long run relationship between the two variables can be generalised as negative, meaning economic growth and stock market development moved contrary to each other during the period under study. It can therefore be concluded that investors tend to move (switch) their capital from the market into real economic activities and vice-versa. Meaning, if the economy is doing well investors shun the stock market for real economic activities and reverse the process if the economy is performing dismally, at least in the long run.

Against this background, it can be noted that the stock market did not significantly contribute much to economic growth, hence the call is being made to the regulatory authorities such as SECZ to ensure transparency and efficiency on the local bourse so that confidence is restored back and new listings can be lured. The same authorities are also recommended to come up with new investment avenues and products so that even small and medium firms can raise funds via the bourse, that is to bring the exchange back to its original economic purpose.

The government and commercial banks at large are recommended to increase their financial support for small firms which cannot raise money from the bourse (but they are currently the major employers and economic engines of the nation). Basically, all the stakeholders should look beyond ZSE to promote economic growth in Zimbabwe. No single institution can handily drive the economic engines of Zimbabwe.

\section{References}

Bagehot, W. (1873). Lombard Street: A Description of the Money Market. London: Henry S King and Company.

Beck, T and Levine, R. (2003). Stock Markets, Banks and Growth: Correlation or Causality. Policy Research Working Paper 2670. World Bank: Washington D.C.

Bernanke, B. (1986). Alternative Explanations of the Money-Income Correlation. In: Carnegie-Rochester Conference Series on Public Policy (incorporated into Journal of Monetary Economics), 25, pp. 49-99.

Bhide, A. (1993). The Hidden Costs of Stock Market Liquidity. Journal of Financial Economics, 34(1), pp. 31-51.

Binswanger, R. (2000). The Relationship between Stock Market Returns and Rates of Inflation. Journal of Finance, 34(3), pp. 743-749.

Boulila, G., and Trabelisi, M. (2002). Financial Development and Long-Run Growth: Granger Causality in Bivariate VAR Structure, Evidence from Tunisia: 1962-1997. FSEGT Working paper.

Calderon, C., and Liu, L. (2003). The Direction of Causality between Financial Development and Economic Growth. Journal of Development Economics, 72(1), pp. 321-334. 
Campbell, J. Y. (1987). Stock Returns and the Term Structure. Journal of Financial Economics, 18(2), pp. 373-399.

Chiwunze, G. (2014). Foreign Investors and the Performance of the Zimbabwe Stock Exchange in the Multicurrency Period. Available at: <http://www.polity.org.za/article/foreign-investors-and-the-performance-of-thezimbabwe-stock-exchange-in-the-multicurrency-period-2014-03-25>.

Comincioli, B. (1996). The Stock Market as a Leading Indicator: An application of Granger Causality. The Park Place Economist, 4, pp. 31-40.

Corporale, G. M., Howells, P. G. A. and Soliman, A. M. (2004). Stock Market Development and Economic Development: A Causal Linkage. Journal of Economic Development, 29(1), pp. 33-50.

Demetriades, P. and Hussein, K. (1996). Does Financial Development Cause Economic Growth? Time Series Evidence from 16 Countries. Journal of Development Economics, 51(2), pp 387-411.

Fry, M. (1995). Money, Interest, and Banking in Economic Development, 2nd ed. London: John Hopkins University Press.

Goldsmith, R. W. (1969). Financial Structure and Development. New Haven, CT: Yale University Press.

Gono, G. (2008). Press statement on the rampant fraudulent activities on the stock exchange, the insurance and pension fund industries and the banking sector. Reserve Bank of Zimbabwe, November 2008. Available at: <http://www.rbz.co.zw/assets/press_zse.pdf>.

Gono, G. (2012). Monetary Policy Statement. Reserve Bank of Zimbabwe, January 2012. Available at: <http://www.rbz.co.zw/assets/mid-term-mps-july-2012.pdf>.

IMARA (2012). Zimbabwe Stock Exchange Overview - May 2012. Available at: <http://www.globalalliancepartners.com/research/IMARA/2012/2012-05-24\%20\%20Zimbabwe\%20Booklet.pdf>.

Inanga, I. L. and Emenuga, C. (1997). Institutional, Traditional and Asset Pricing Characteristics of the Nigerian Stock Exchange. African Economic Research Consortium. Research paper 60.

Islam, R., Habib, W. and Khan, H. (2004). A Time Series Analysis of Finance and Growth in Bangladesh. The Bangladesh Development Studies, 30(1/2), pp. 111-128.

Jecheche, P. (2011). The Effect of the Stock Exchange on Economic Growth: A Case of the Zimbabwe Stock Exchange. Research in Business and Economics Journal, pp. 1-17. Available at: <http://www.aabri.com/manuscripts/111088.pdf>.

Johansen, S., and Juselius, K. (1992). Testing Structural Hypothesis in a Multivariate Cointegration Analysis of the PPP and UIP for UK. Journal of Econometrics, 53(1-3), pp. 211-244.

King, R.G. and Levine, R. (1993). Finance and Growth: Schumpeter Might be Right. Quarterly Journal of Economics, 108(3), pp. 717-737.

Levine, R. (1997). Financial Development and Economic Growth: Views and Agenda. Journal of Economic Literature, 35(2), pp. 688-776.

Levine, R. (1999). Law, Finance and Economic Growth. Journal of Financial Intermediation, 8(1), pp. 36-67.

Levine, R. (2004). Finance and Growth: Theory and Evidence. Working Paper 10766, National Bureau of Economic Research. Available from: <http://www.nber.org/papers/w10766>. 
Levine, R. and Zervos, S. (1998). Stock Markets, Banks, and Economic Growth. American Economic Review, 3(88), pp. 537-558.

Levine, R., (1997). Financial Development and Economic Growth: Views and Agenda. Journal of Economic Literature, 35(2), pp. 688-726.

Levine, R., Loayza, N., Beck, T. (2000). Financial Intermediation and Growth Causality and Causes. Journal of Monetary Economics, 46(1), pp. 31-77.

Lyton-Edwards (2011). Stockbrokers. Available at: <http://lynton-edwards.com/>.

Maduka, C. and Onwuka, K. O. (2013). Financial Market Structure and Economic Growth: Evidence from Nigeria Data. Asian Economic and Financial Review, 3(1), pp. 75-98.

Mckinnon, R. I. (1973). Money and capital in economic development. Washington, D.C.: Brooking Institution.

Ndlovu G. (2013). Financial Sector Development and Economic Growth: Evidence from Zimbabwe. International Journal of Economics and Financial Issues, 3(2), pp. 435-446.

Nowbutsing, B. M. (1999). Stock Market Development and Economic Growth: The Case Of Mauritius. International Business and Economics Research Journal, 8(2), pp. 77-88.

Nyong, M. O. (1997). Capital Market Development and Long-Run Economic Growth: Theory, Evidence and Analysis. First Bank Review, pp. 13-38.

Patrick, H. T. (1966). Financial Development and Economic Growth in Underdeveloped Countries. Economic Development and Cultural Change, 14(1), pp. 174-189.

Perron, P. (1989). The Great Crash, the Oil Price and the Unit Root Hypothesis. Econometrica, 57(6), pp. 1361-1401.

Perron, P. (1990). Testing for Unit Root in a Time Series with Changing Mean. Journal of Business and Economic Statistics, 8(2), pp. 153-162.

Robinson, J. (1952). The Rate of Interest and Other Essays. London: Macmillan.

Rousseau, P. L., and Wachtel, P. (2000). Equity Markets and Growth: Cross Country Evidences on Timing and Outcomes. Journal of Banking and Finance, 24, pp. 19331957.

Rubin Leah H., Witkiewitz, K., Andre, J. St. and Reilly, S. (2007). Methods for Handling Missing Data in the Behavioral Neurosciences: Don't Throw the Baby Rat out with the Bath Water. The Journal of Undergraduate Neuroscience Education, 5(2), pp. A71-A77.

Schumpeter, J. A. (1912). Theorie der Wirtschaftlichen Entwicklung (The Theory of Economic Development). Translated by Redvers Opie Cambridge, MA: Havard University Press.

Singh, A. (1997). Financial Liberalization, Stock Markets and Economic Development. The Economic Journal, 107, pp. 771-782.

Tuncer, C. and Alovsat, M. (2001). Stock Markets and Economic Growth: A Causality Test. Institute of Social Science, Istanbul Technical University.

Van Nieuwerburgh, S., Buelens, F. and Cuyvers, L. (2005). Stock Market Development and Economic Growth in Belgium. New York: Stern School of Business.

Zivengwa, T., Mashika, J., Fanwell, K. B., and Makova, T. (2011). Stock Market Development and Economic Growth in Zimbabwe. International Journal of Economics and Finance, 3(5), pp. 140-150. 